\title{
From the Editors - Redactioneel
}

Op 12 mei 2017 vond het KNHG-voorjaarscongres 'Nieuwe staat, nieuwe burgers? Burgerschap in de Lage Landen, 1750-1850' plaats in Amsterdam. Het congres was een van de resultaten van het streven van het KNHG en BMGN - Low Countries Historical Review naar een meer integrale behandeling van de geschiedenis van de Lage Landen. Gedurende het congres bleek niet geheel onverwacht dat het zoeken naar overeenkomsten en dwarsverbanden in de politieke en sociale geschiedenis van de gebieden die in 1815 het Koninkrijk der Nederlanden zouden vormen, op forse culturele en politieke verschillen stuitte. Maar op het congres werd ook duidelijk dat die verschillen niet een op een terug te voeren waren op het verloop van de staatkundige ontwikkeling van de Noordelijke en de Zuidelijke Nederlanden. De bijdragen aan het congres zijn bijeengebracht in dit nummer van de BMGN, met uitzondering van de bijdrage van Marjolein 't Hart en Hilde Greefs die vanwege de enigszins afwijkende thematiek reeds in het vorige nummer van de BMGN is gepubliceerd. Gastredacteuren van dit nummer zijn Joris Oddens en Diederik Smit, die tevens het KNHG-congres hebben georganiseerd, samen met het onvolprezen bureau van het KNHG. Oddens en Smit benadrukken dat hun doel vooral is om bestaande vooronderstellingen kritisch tegen het licht te houden. Tegenover de dominante visie van de periode rond 1800 als een breukvlak tussen vroegmoderne en moderne geschiedenis, hebben zij de geschiedenis van de Lage Landen in deze periode vooral in het licht van continuïteit willen behandelen. De artikelen toetsen in hoeverre het Koninkrijk van 1815 was gebouwd op vroegere structuren, praktijken en identiteiten, die veelal pas aan het licht komen als de aandacht wordt verlegd van de nieuwe staat naar het regionale, lokale of zelfs het individuele niveau.

Dit laatste blijkt uit de bijdragen van Carolien Boender over burgermilities en de persistentie van stedelijk burgerschap, van Marjolein Schepers over de continuïteit in lokale verbanden in de armenzorg en van Joris Oddens en Jane Judge over de sterke overeenkomsten in de taal van armenbrieven aan de stadhouder of vorst. Juist op het politiekbestuurlijke niveau bleven de verschillen tussen Noord en Zuid groot. Diederik Smit en Brecht Deseure analyseren in hun bijdrage de opvallende verschillen in de uitgangspunten voor de inrichting van het provinciaal bestuur in Noord en Zuid in het Koninkrijk na 1815. Lauren Lauret legt in haar bijdrage de scherpe en onverzoenlijke tegenstellingen in de parlementaire cultuur bloot zoals die vanaf 1815 naar boven kwam in de heftige confrontaties tussen Noordelijke en Zuidelijke afgevaardigden in de Staten Generaal. De vijf thematische artikelen worden voorafgegaan door een beschouwing over de ontwikkelingen in de historiografie over de bestudeerde periode in Noord en Zuid van de hand van Judith Pollmann en Henk te Velde, de initiators van het KNHG-congres. Het congres en dit themanummer hebben in de ogen van de gastredacteuren Oddens en Smit en de redactie 
van de BMGN laten zien dat er onder historici een breed gedeelde overtuiging heerst dat de kunstmatige scheiding tussen vroegmodern en modern en tussen Noord en Zuid moet worden overbrugd. Dit themanummer is een mogelijke katalysator voor verdergaande discussie en grensoverschrijdende onderzoekssamenwerking.

Binnen de redactie van BMGN hebben enkele verschuivingen plaatsgevonden. Dirk Jan Wolffram heeft in september het voorzittersstokje overgenomen van Kaat Wils, die de redactie twee jaar met veel enthousiasme en inzet geleid heeft. Frederik Buylaert treedt de komende periode als vicevoorzitter op. Ook op het redactiebureau is een verandering te melden: Anne-Marie Mreijen is per 1 september opgevolgd door Tessa Lobbes.

Namens de redactie,

\section{From the Editors - Editorial}

On 12 May 2017, the KNHG spring congress New State, New Citizens? Citizenship in the Low Countries, 1750-1850 was held in Amsterdam. This event was organised in the context of the quest of the KNHG and the BMGN - Low Countries Historical Review of a more comprehensive approach to the history of the Low Countries. As expected, the search for similarities, dissimilarities and entanglements in the political and social history of the regions that came to constitute the Kingdom of the Netherlands in 1815 revealed significant cultural and political differences, which cannot be reduced to the preceding political trajectories of the Northern and Southern Netherlands. This issue of BMGN features articles that are based on the papers delivered at the congress (excepting the contributions of Marjolein 't Hart and Hilde Greefs, which were more suitable for publication in the previous issue of BMCN). The guest editors of this issue are Joris Oddens and Diederik Smit, who also organised the KNHG Congress, together with the much appreciated help of the staff of KNHG. The key contention of Oddens and Smit is that some deep-rooted assumptions on the history of the Kingdom of the Netherlands need revision. Countering the dominant perception of the period around 1800 as a watershed between the 'Early Modern' and 'Modern' age, they stress the continuity between this phase of the history of the Low Countries with the preceding era. The articles of this issue probe the extent to which the Kingdom of 1815 was shaped by preexisting structures, practices, and identities, forms of continuity which only come to light if the scholarly focus is shifted from the newly established state to the regional, local, or even individual sphere.

This revisionist perspective underpins the article of Carolien Boender on civic militias and the persistence of municipal citizenship, that of Marjolein Schepers on the continuity of poor relief in local contexts and that of Joris Oddens and Jane Judge on close similarities in the wording of pauper letters to the stadtholder or ruler. Other articles reveal that substantial differences persisted in political and administrative practices in the North and South. Diederik Smit and Brecht Deseure have analysed striking differences between the premises underlying the structure of provincial government in North and South in the Kingdom after 1815. Lauren Lauret has contributed a paper revealing the deep and irreconcilable contrasts in parliamentary culture that emerged from 1815 in the clashes 
between Northern and Southern delegates in the States General. These five articles are preceded by critical reflections of Judith Pollmann and Henk te Velde, the two scholars who organised the KNHG Congress. Guest editors Oddens and Smit and the BMGN editors argue that the congress and this special issue demonstrate that historians are united in their wish to bridge the artificial distinction between North and South during the early-modern and modern periods. This special issue aspires to spark further debate and cross-border research collaborations.

There have been some changes on the BMGN editorial board. In September Dirk Jan Wolffram became chairman, succeeding Kaat Wils, who chaired the editorial board with great dedication. Frederik Buylaert will serve as vice-chairman in the coming period. Last but not least, the position at the secretariat of the editorial board that was hitherto filled by AnneMarie Mreijen will pass to Tessa Lobbes on 1 September.

On behalf of the editorial board, 